\title{
Comparative Metal Distribution in Scalp Hair of Pakistani and Irish Referents and Hypertensive Patients
}

Hassan Imran Afridi \& Dermot Brabazon \& Tasneem Gul Kazi \& Sumsun Naher \& Ekaterina Nesterenko.

Keywords Scalp hair. Zinc, Toxic elements, Pakistani hypertensive patients, Irish hypertensive patients. Atomic absorption spectrophotometer, Inductively coupled plasmaatomic emission spectrophotometer.

\begin{abstract}
The abnormal metabolism of metal ions plays an important role in health and disease conditions, and studies about them have been attracting significant interest. The aim of our study was to assess the heavy metals (cadmium $(\mathrm{Cd})$, nickel $(\mathrm{Ni})$, lead $(\mathrm{Pb})$, and zinc $(\mathrm{Zn})$ ) in scalp hair samples of 50 Irish and 78 Pakistani hypertensive patients of an urban population together with 50 fish and 96 Pakistani non-hypertensive male subjects in the age group of 3050 years. The concentrations of trace and toxic elements were measured by inductively coupled plasma-atomic emission spectrophotometer and atomic absorption spectrophotometer before microwave-assisted acid digestion. The validity and accuracy of the methodology were checked using certified reference materials, and by the conventional wet acid digestion method on the same certified reference materials and on real samples. The recovery of all the studied elements was found to be in the range of $97.5-99.7 \%$ in certified reference material. The results of this study showed that the mean values of cadmium, nickel, and lead were significantly higher in scalp hair samples of both Pakistani and Irish hypertensive patients than in referents $(\mathrm{p}<0.001)$, whereas, the concentration of zinc was lower in the scalp hair samples of hypertensive patients of both genders. The deficiency of zinc and the high exposure of trace and toxic metals may be the risk factors associated with hypertension.
\end{abstract}

\section{Introduction}

Hypertension (HT) is an increasingly important medical and public health issue. The prevalence of HT increases with advancing age (60-90 years) [1]. But nowadays, the age criteria have been changed and even people below 30 years of age have HT problems because of the lack of exercise, fast foods, smoking, coffee, and alcohol consumption [2]. Genetic effect may also be a factor [3]. The essential trace element zinc ( $\mathrm{Zn}$ ) is an important component of biomembranes and an essential cofactor in a variety of enzymes [4]. Zinc has antioxidant-like properties; thus, it can stabilize macromolecules against radical-induced oxidation in vitro as well as limit excess radical production [5]. Zinc deficiency is associated with an increase in $\mathrm{Cd}$, as a result of the antagonistic relationships between these elements [6].

Toxic metals play a vital role in diseases of unknown etiology. Many researchers have studied the relationship of cadmium $(\mathrm{Cd})$, lead $(\mathrm{Pb})$, zinc, and nickel $(\mathrm{Ni})$ to hypertensive status using hair as a biopsy material [7-9]. The exposure of these toxic metals occurred 
mainly through cigarette smoking, inhalation of airborne cadmium, lead and nickel in ambient air (usually higher near coal-fired power plants and municipal waste incinerators), or consumption of some foods (highest levels in shellfish, and liver and kidney meats).[10] In urban areas, the use of concrete and the combustion of oil, coal, and gasoline represent the major potential sources of environmental pollution for toxic metals [11] and toxic metals containing particles may thus easily find their way into the respiratory tract [11]. Certain metals may promote hypertensive and atherosclerosis by increasing oxidative stress (e.g., by catalyzing the production of reactive oxygen species or inhibiting their degradation) and increasing the blood pressure levels $[12,13]$.

The intake of trace and toxic elements may promote hypertensive and atherosclerosis disorders by increasing oxidative stress (for example, by catalyzing the production of reactive oxygen species or inhibiting their degradation) due to the deficiency of an antioxidant element (Zn) and by increasing blood pressure levels [13]. The deficiency of essential nutrients, lack of homeostatic control or an excess intake of some TEs causes chronic physiological disorders, such as HT and cardiovascular disease [14].

Determinations of trace elements in human tissues and fluids were used to obtain information on nutritional status for diagnosis of diseases, indication of systemic intoxication, and to obtain information on environmental exposure. In the majority of cases, whole blood, serum, plasma, and urine were analyzed [15]. Hair can provide a more permanent record of trace and toxic elements associated with normal and abnormal metabolism as well as toxic elements assimilated from the environment. In addition, hair is easily collected, conveniently stored, and easily treated. Therefore, the analysis of human hair has become an important way to understand any quantitative change in certain elements inside the body [16]. One of the most widely used analytical technique for different elements determination in biological and environmental materials is inductively coupled plasma - atomic emission spectrometry (ICPAES) due to its advantages over other analytical methods: above all, a possibility of simultaneous determination of many elements of interest, freedom from different chemical interferences, and high detection power. ICP-AES also offers rapid, multi-element determinations. The sensitivity of ICP-AES is lower than that of either inductive coupled plasma - mass spectrophotometer (ICP-MS) or atomic absorption graphite tube atomizer (AA-GTA), but ICP-AES can handle higher levels of total dissolved solids (TDS) than ICPMS and is much faster than AA-GTA. Since ICP-AES is able to analyze samples with higher TDS, more concentrated solutions can be prepared allowing trace elements to be measured. The main advantage of microwave-assisted samples pretreatment is its requirement of small amount of mineral acids and a reduction in the production of nitrous vapors. Microwave systems keep blank levels low because only small volumes of reagents are required and allow more samples to be processed per hour than conventional digestion systems [17].

Accordingly, the present study envisaged a comparative distribution of selected metals $(\mathrm{Cd}$, $\mathrm{Ni}, \mathrm{Pb}$, and $\mathrm{Zn}$ ) in the hair of a segment of Pakistani and fish referents and hypertensive patients of age group (30-50) years. The donors of both gender from both countries, with matched age groups and belonging to a matched typical urban residence, were selected for the study. The metal levels were examined for a possible mutual correlation also, and were 
compared with reported metal levels for donors from other regions of the world. It was anticipated that the comparative metal levels in hair of Pakistani and Irish referent segments would bring out distinct sources responsible for the distribution of selected metals to help assess the nutritional status and environmental exposure of the two categories of subjects compared with those from other nations where different environmental and living conditions prevail.

\section{Materials and Methods}

\section{Apparatus}

The analysis of elements in Ireland was carried out by means of Varian Liberty 220 (Mulgrave, Victoria, Australia) inductively coupled plasma - atomic emission spectrometer with the axially viewed plasma was used for the analysis. The Liberty Series II ICP features a $40-\mathrm{MHz}$ free running RF generator, a 0.75-m Czerny-Turner monochromator with 1,800 grooves per millimeter holographic grating used in up to four orders. The resolution of the spectrometer is typically $0.018 \mathrm{~nm}$ in the first order, $0.009 \mathrm{~nm}$ in the second order, $0.007 \mathrm{~nm}$ in the third order, and $0.006 \mathrm{~nm}$ in the fourth order. The instrument was controlled with a Digital Equipment Corporation Venturis computer with an Intel Pentium processor and Varian Plasma 96 software running under Microsoft Windows 95 operating system. The instrumental conditions are shown in Tables 1 and 2. A Hinari Life style (Elstree, Hertfordshire, England) domestic microwave oven (maximum heating power of $800 \mathrm{~W}$ ) was used for digestion of the scalp hair samples.

The analysis of elements in Pakistan was carried out by means of a double beam PerkinElmer atomic absorption spectrometer model 700 (Norwalk, CT, USA), equipped with a flame burner and graphite furnace HGA-400, a pyrocoated graphite tube with an integrated platform and an autosampler AS-800 (PerkinElmer). The instrumental parameters are shown in Tables 3 and 4. Zn was measured under optimized operating conditions using FAAS with an air-acetylene flame, whereas $\mathrm{Cd}, \mathrm{Ni}$, and $\mathrm{Pb}$ were determined using ETAAS. Signals were measured as absorbance peaks in the flame absorption mode, whereas integrated absorbance values (peak area) were determined in the graphite furnace. A Pel (PMO23, Osaka, Japan) domestic microwave oven (maximum heating power of $900 \mathrm{~W}$ ) was used for digestion of the biological samples. Acid-washed polytetrafluoroethylene (PTFE) vessels (Kartell, Milan, Italy) and flasks were used for preparing and storing solutions.

\section{Reagents and Glasswares}

Ultrapure water obtained from ELGA Lab Water system (Bucks, UK) was used throughout the work. Concentrated nitric acid (65\%) and hydrogen peroxide (30\%) were obtained from Merck (Darmstadt, Germany), and checked for possible trace metal contamination. Working standard solutions of $\mathrm{Cd}, \mathrm{Ni}, \mathrm{Pb}$, and $\mathrm{Zn}$ were prepared immediately prior to their use, by 
stepwise dilution of certified standard solutions (1,000 ppm) Fluka Kamica (Buchs, Switzerland), with $0.5 \mathrm{M}$ HNO3.

Table 1 Measurement conditions for inductively coupled plasma-atomic emission spectroscopy Liberty 220 ICP-AES

\begin{tabular}{|c|c|c|c|c|}
\hline Parameters & $\mathrm{Cd}$ & $\mathrm{Ni}$ & $\mathrm{Pb}$ & $\mathrm{Zn}$ \\
\hline Wavelength (nm) & 226.502 & 231.604 & 220.553 & 213.8 \\
\hline Height (mm) & 3 & 5 & 3 & 5 \\
\hline Windows (nm; above the coil) & 0.027 & 0.027 & 0.027 & 0.027 \\
\hline Scan $(n m)$ & 0.040 & 0.040 & 0.040 & 0.040 \\
\hline Integration (s) & 3 & 3 & 3 & 3 \\
\hline Replicates & 3 & 3 & 3 & 3 \\
\hline Sample uptake (s) & 30 & 30 & 30 & 30 \\
\hline PMT (V) & 650 & 650 & 650 & 650 \\
\hline Power (kW) & 1.10 & 1.10 & 1.10 & 1.10 \\
\hline Plasma flow (L/min) & 15.0 & 15.0 & 15.0 & 15.0 \\
\hline Auxiliary flow (L/min) & 1.50 & 1.50 & 1.50 & 1.50 \\
\hline Pump speed (rpm) & 15 & 15 & 15 & 15 \\
\hline Background mode & Dynamic & Dynamic & Dynamic & Dynamic \\
\hline Max curve order & 1 & 1 & 1 & 1 \\
\hline C.C. limit & 0.995 & 0.995 & 0.995 & 0.995 \\
\hline \multicolumn{3}{|l|}{ Nebulizer type } & \multicolumn{2}{|c|}{ V-groove } \\
\hline \multicolumn{3}{|l|}{ Nebulizer pressure } & \multicolumn{2}{|c|}{$150 \mathrm{kPa}$} \\
\hline \multicolumn{3}{|l|}{ Stabilization time } & \multicolumn{2}{|c|}{$10 \mathrm{~s}$} \\
\hline \multicolumn{3}{|l|}{ Sample delay time } & \multicolumn{2}{|c|}{$30 \mathrm{~s}$} \\
\hline \multicolumn{3}{|l|}{ Rinse time } & \multicolumn{2}{|c|}{$10 \mathrm{~s}$} \\
\hline \multirow[t]{2}{*}{ Pump-tube } & & & \multicolumn{2}{|c|}{ Orange-orange (inlet) } \\
\hline & & & \multicolumn{2}{|c|}{ Blue-blue (outlet) } \\
\hline \multicolumn{2}{|l|}{ Snout purge } & & \multicolumn{2}{|c|}{ Off } \\
\hline \multicolumn{2}{|l|}{ Fast pump } & & \multicolumn{2}{|l|}{ On } \\
\hline
\end{tabular}

\begin{tabular}{|llll}
\hline Table 3 & \multicolumn{3}{l}{} \\
\hline Parameters & $\mathrm{Cd}$ & $\mathrm{Ni}$ & $\mathrm{Pb}$ \\
\hline Lamp current (MA) & 6.0 & 3.5 & 8.0 \\
Wave length (nm) & 228.8 & 232.0 & 283.3 \\
Slit width (nm) & 0.7 & 0.2 & 0.7 \\
Dry temperature $\left({ }^{\circ} \mathrm{C}\right) / \mathrm{ramp} / \mathrm{hold}(\mathrm{s})$ & $140 / 15 / 5$ & $140 / 15 / 5$ & $140 / 15 / 5$ \\
Ashing temperature $\left({ }^{\circ} \mathrm{C}\right) / \mathrm{ramp} / \mathrm{hold}(\mathrm{s})$ & $850 / 10 / 20$ & $1,000 / 10 / 20$ & $700 / 10 / 20$ \\
Atomization temperature $\left({ }^{\circ} \mathrm{C}\right) / \mathrm{ramp} / \mathrm{hold}(\mathrm{s})$ & $1,650 / 0 / 5.0$ & $2,300 / 0 / 5.0$ & $1,800 / 0 / 5.0$ \\
Cleaning temperature $\left({ }^{\circ} \mathrm{C}\right)(\mathrm{ramp} / \mathrm{hold})(\mathrm{s})$ & $2,600 / 1 / 3$ & $2,600 / 1 / 3$ & $2,600 / 1 / 3$ \\
Chemical modifier & $\left.\mathrm{Mg}\left(\mathrm{NO}_{3}\right)_{2}+\mathrm{Pd}_{(\mathrm{NO}}\right)_{2}$ & $\mathrm{Mg}\left(\mathrm{NO}_{3}\right)_{2}$ & $\mathrm{Mg}(\mathrm{NO})_{2}$ \\
\hline
\end{tabular}

Sample volume $(10 \mu \mathrm{l})$, cuvette $=$ cup, carrier gas $=(200 \mathrm{ml} / \mathrm{min})$ background correction $\left(\mathrm{D}_{2}\right.$ lamp $)$ used for all elements

\begin{tabular}{|llr} 
Table 4 & Measurement conditions & \\
for $\mathrm{Zn}$ & Wave length (nm) & 214 \\
& Slit width (nm) & 0.7 \\
& Lamp current (mA) & 7.5 \\
& Burner height (mm) & 7.5 \\
& Oxidant (air) $1 \mathrm{~min}^{-1}$ & 17.0 \\
& Fuel (acetylene) $1 \mathrm{~min}^{-1}$ & 2.0 \\
\hline
\end{tabular}


All solutions were stored in polyethylene bottles at $4^{\circ} \mathrm{C}$. For the accuracy of methodology, the certified reference materials (CRMs), human hair NCSZN 81002b (Beijing, China), and certified reference materials of human hair BCR 397 (Brussels®, Belgium) were used (Table 5). All glassware and plastic materials used were previously soaked for $24 \mathrm{~h}$ in $5 \mathrm{M}$ nitric acid, washed with distilled and finally rinsed with ultrapure water, dried, and stored in a class 100 laminar flow hoods.

\begin{tabular}{|c|c|c|c|c|c|}
\hline Elements & $\begin{array}{l}\text { Conventional digestion } \\
\text { method CDM }\end{array}$ & $\begin{array}{l}\text { Microwave digestion } \\
\text { method MWD }\end{array}$ & $T$ value $^{\mathrm{a}}$ & $\%$ Recovery $^{\mathrm{b}}$ & $\begin{array}{l}\text { Certified } \\
\text { values }\end{array}$ \\
\hline \multicolumn{6}{|c|}{ Certified human hair reference material (NCS ZC 81002b) $(\mu \mathrm{g} / \mathrm{g})$} \\
\hline $\mathrm{Cd}$ & $0.0716 \pm 0.003(4.19)$ & $0.0714 \pm 0.006(8.40)$ & 0.305 & 99.7 & $0.072 \pm 0.010$ \\
\hline $\mathrm{Ni}$ & $5.71 \pm 0.51(8.93)$ & $5.67 \pm 0.43(7.58)$ & 0.339 & 99.4 & $5.77^{\mathrm{c}}$ \\
\hline $\mathrm{Pb}$ & $3.80 \pm 0.37(9.74)$ & $3.72 \pm 0.35(9.41)$ & 0.081 & 98.05 & $3.83 \pm 0.18$ \\
\hline $\mathrm{Zn}$ & $191 \pm 7.28(3.81)$ & $187 \pm 9.53(5.09)$ & 0.648 & 97.9 & $191 \pm 16$ \\
\hline \multicolumn{6}{|c|}{ Certified human hair material CRM $397(\mu \mathrm{g} / \mathrm{g})$} \\
\hline $\mathrm{Cd}$ & $0.53 \pm 0.025(4.72)$ & $0.524 \pm 0.024(4.58)$ & 0.2256 & 98.87 & $0.52 \pm 0.024$ \\
\hline $\mathrm{Ni}$ & $46.07 \pm 1.41(3.06)$ & $45.75 \pm 1.38(3.02)$ & 0.9242 & 99.3 & $46.0 \pm 1.4^{\#}$ \\
\hline $\mathrm{Pb}$ & $33.29 \pm 1.21(3.63)$ & $32.56 \pm 1.18(3.62)$ & 0.096 & 97.8 & $33 \pm 1.2$ \\
\hline $\mathrm{Zn}$ & $197 \pm 12.8(6.2)$ & $194 \pm 11.3(5.7)$ & 0.0345 & 98.6 & $199 \pm 5$ \\
\hline \multicolumn{6}{|c|}{ Values in parentheses are $\mathrm{RSD} . \mathrm{DF}=9, T$ (critical) at $95 \% \mathrm{CI}=2.262, p=0.05$} \\
\hline \multicolumn{6}{|c|}{ \# Indicative value } \\
\hline \multicolumn{6}{|c|}{ a Paired $t$ test between CDM and MWD } \\
\hline \multicolumn{6}{|c|}{ b Calculated according to: $\frac{[\mathrm{MDM}]}{[\mathrm{CDM}]} \times 100$} \\
\hline \multicolumn{6}{|c|}{ c Means in percentage } \\
\hline
\end{tabular}

\section{Experimental}

\section{Collection of Scalp Hair Samples}

The study was completed in two phases. Phase 1 was completed during June 2005 to December 2005 and phase 2 during July to October 2010. The sampling locations were Hyderabad, Pakistan, and Dublin, Ireland. The donor ages of both genders ranged between 30-50 years from each location. The details related to a donor's identity, residence, food habits, health status, socio-economic status, and education were recorded on a regular proforma at the time of sampling. Before the start of this study, all the control subjects and HT patients were informed about the aim of the study by being administered a form, and all agreed to participate and signed the form. A questionnaire was administered to them in order to collect details concerning physical data, ethnic origin, health, and dietary and smoking habits. Physical examinations were performed to measure participants' weight, height, blood pressure, and biochemical data. There were no statistically significant differences between normal and hypertensive patients regarding height, weight, or comparable aspects of family. The total number of normal and hypertensive subjects is shown in Table 6 . The hypertensive patients who had blood pressure exceeding 130/95 mmHg (systolic/ diastolic) were admitted for their uncontrolled HT and had earlier histories of high blood pressure. The criteria of 
healthy subjects included no history of symptoms of hypertension and any coronary disease documented in their medical notes, and no family history of heart disease was defined by a first-degree relative with a myocardial infarction, or cardiac death before the age of 55 years. All control subjects underwent a routine medical examination including myocardial infarction test. All patients and controls/referents were requested to complete an intervieweradministered questionnaire, concerning their demographic characteristics, age, health history, lifestyle habits, and diet. They gave written consent to participate in the study.

\begin{tabular}{|c|c|c|c|c|}
\hline \multirow[t]{2}{*}{ Countries } & \multicolumn{2}{|l|}{ Male } & \multicolumn{2}{|l|}{ Female } \\
\hline & Referents & Hypertensive patients & Referents & Hypertensive patients \\
\hline Pakistan & 51 & 40 & 45 & 38 \\
\hline Ireland & 27 & 24 & 23 & 26 \\
\hline
\end{tabular}

\section{Collection of Scalp Hair Samples}

The hair samples (-1.0 g each) were taken from the nape of the neck. Hair samples were put into separate plastic envelopes for each participant, on which the identification number of the participant was indicated. The plastic envelope of each subject was tightly sealed and attached to a questionnaire. Before analysis, each individual hair sample was cut into approximately $0.5-\mathrm{cm}$-long pieces and mixed to allow a representative subsampling of the hair specimen. After cutting, each sample was washed with diluted Triton X-100: samples were then rinsed with distilled water and then with deionized water. The samples were then rinsed three times with acetone [17]. The samples were then dried in an oven at $75 \pm 5^{\circ} \mathrm{C}$ for 2 h. Dried samples were stored separately in polyethylene bags.

\section{Microwave-Assisted Acid Digestion}

A microwave-assisted digestion (MWD) procedure was carried out, in order to achieve a shorter digestion time. Duplicate samples of scalp hair $(200 \mathrm{mg})$ of each hypertensive patients and control individuals were directly placed into Teflon PFA flasks. Two milliliters of a freshly prepared mixture of concentrated $\mathrm{HNO}_{3}-\mathrm{H}_{2} \mathrm{O}_{2}(2: 1$, v/v) were added to each flask and kept for $10 \mathrm{~min}$ at room temperature then placed in a covered PTFE container. This was then heated following a one-stage digestion program at $80 \%$ of total power $(800 \mathrm{~W})$. Complete digestion of scalp hair samples required 5-8 min. After the digestion, the flasks were left to cool and the resulting solution was evaporated to semidried mass to remove excess acid. About $5 \mathrm{ml}$ of $0.1 \mathrm{M}$ nitric acid was added to the residue and filtered through a Whatman no. 42 filter paper and diluted with deionized water up to $10.0 \mathrm{ml}$ in volumetric flasks. Blank extractions were carried through the complete procedure. Blanks and standard solutions were prepared in a similar acid matrix. The validity and efficiency of the MWD 
method was checked with certified values of human hair NCSZC 81002b and certified human hair CRM 397 and with those obtained from conventional wet acid digestion method [15].

\section{Analytical Figures of Merit}

Statistical analyses were performed using computer program Excel XL State (Microsoft Corp., Redmond, WA, USA) and Minitab 13.2 (Minitab Inc., State College, PA, USA). Calibration was performed with a series of $\mathrm{Cd}, \mathrm{Ni}, \mathrm{Pb}$, and $\mathrm{Zn}$ standards. Sensitivity (m) was the slope value obtained by least-square regression analysis of calibration curves based on peak area measurements. The linear range of the calibration curve ranged from the quantification limit up to $100 \mu \mathrm{g} / 1$ was used for all trace and toxic elements. The limit of detection, equal to $0.0003,0.01,0.0003$, and $0.01 \mathrm{ng} / \mathrm{mg}$ for $\mathrm{Cd}, \mathrm{Ni}, \mathrm{Pb}$, and $\mathrm{Zn}$, respectively, was defined as $3 \mathrm{~s} / \mathrm{m}$, "s" being the standard deviation corresponding to ten blank injections and " $\mathrm{m}$ " the slope of the calibration graph. The quantification limits, defined as $10 \mathrm{~s} / \mathrm{m}$ were calculated as: $0.0009,0.05,0.001$, and $0.04 \mathrm{ng} / \mathrm{mg}$ for $\mathrm{Cd}, \mathrm{Ni}, \mathrm{Pb}$, and $\mathrm{Zn}$, respectively.

\section{Result}

The analytical results of hair provide a more permanent record of the trace elements than blood and urine analysis [18]. Its values, therefore, are valuable in forensic studies, environmental investigation, nutritional status, and clinical diagnosis. Analytical results of the CRM 397 and NCS ZC 81002b obtained by both digestion methods were close to that of the certified values, which confirmed the reliability of the methods (Table 5). The analysis of normal and patient scalp hair samples is reported as mean values with standard deviation (SD) and $\mathrm{p}$ values reported for each element (Tables 7 and 8).

\begin{tabular}{|c|c|c|c|c|c|c|}
\hline \multirow[t]{2}{*}{ Elements } & \multicolumn{3}{|l|}{ Male } & \multicolumn{3}{|l|}{ Female } \\
\hline & Referents & Hypertensive patients & $p$ Value & Referents & Hypertensive patients & $p$ Value \\
\hline Cadmium & $0.72 \pm 0.08$ & $2.4 \pm 0.19$ & 0.001 & $0.62 \pm 0.13$ & $1.99 \pm 0.16$ & 0.001 \\
\hline Nickel & $1.86 \pm 0.34$ & $3.97 \pm 0.23$ & 0.001 & $1.65 \pm 0.27$ & $3.59 \pm 0.31$ & 0.001 \\
\hline Lead & $3.36 \pm 0.45$ & $5.18 \pm 0.11$ & 0.001 & $3.25 \pm 0.39$ & $5.09 \pm 0.17$ & 0.001 \\
\hline Zinc & $278 \pm 9.62$ & $185 \pm 19.3$ & 0.001 & $269 \pm 7.53$ & $193 \pm 14.6$ & 0.001 \\
\hline \multicolumn{7}{|c|}{$\begin{array}{l}\text { Table } 8 \text { Concentrations of trace and toxic metals in scalp hair samples of Pakistani referent and hypertensive } \\
\text { subjects }(\mu \mathrm{g} / \mathrm{g})\end{array}$} \\
\hline \multirow[t]{2}{*}{ Elements } & \multicolumn{3}{|l|}{ Male } & \multicolumn{3}{|l|}{ Female } \\
\hline & Referents & Hypertensive patients & $p$ Value & Referents & Hypertensive patients & $p$ Value \\
\hline Cadmium & $1.68 \pm 0.3$ & $2.98 \pm 0.2$ & 0.009 & $1.6 \pm 0.25$ & $2.5 \pm 0.5$ & 0.021 \\
\hline Nickel & $4.3 \pm 1.2$ & $7.8 \pm 1.62$ & 0.001 & $3.9 \pm 1.15$ & $7.5 \pm 1.21$ & 0.001 \\
\hline Lead & $6.24 \pm 0.5$ & $8.35 \pm 1.27$ & 0.014 & $5.58 \pm 1.2$ & $7.56 \pm 1.25$ & 0.016 \\
\hline Zinc & $230 \pm 17.1$ & $165 \pm 18.9$ & 0.003 & $250 \pm 19.3$ & $178 \pm 15.3$ & 0.009 \\
\hline
\end{tabular}


Average metal concentrations ( $\mu \mathrm{g} / \mathrm{g}$, dry weight) along with some basic statistical parameters pertaining to the distribution of the selected metals in scalp hair of Irish and Pakistani hypertensive and referent donors are given in Tables 7 and 8, respectively.

The concentrations of $\mathrm{Zn}$ in the scalp hair samples of male and female Irish referents were significantly higher at $95 \%$ confidence interval (CI) $(266,289)$ and $(260,280) \mu \mathrm{g}$, respectively, compared with those in male and female Irish hypertensive patients, (CI, 164, $205)$ and $(\mathrm{CI}, 178,209) \mu \mathrm{g} / \mathrm{g}$, respectively, with $\mathrm{p}<0.001$. The Zn levels in the scalp hair samples of male and female Pakistani referents, (CI, 213, 248) and (CI, 230, 271) ['gig, respectively, were found to be higher than those in male and female Pakistani hypertensive patients, $(\mathrm{CI}, 144,186)$ and $(\mathrm{CI}, 163,195) \mu \mathrm{g} / \mathrm{g}$, respectively, $(\mathrm{p}>0.001)$.

For both categories of donors, $\mathrm{Cd}, \mathrm{Ni}$, and $\mathrm{Pb}$ showed the highest metal levels in scalp hair samples of hypertensive patients. The concentrations of $\mathrm{Cd}$ in the scalp hair samples of male and female Irish hypertensive patients were significantly lower at 95\% confidence interval $(220,263)$ and $(182,218)$ ['gig, respectively, compared with those in male and female referents, (CI, 0.65, 0.81) and (CI, 0.48, 0.79) ['gig, respectively, with p<0.001 (Table 7). The $\mathrm{Cd}$ levels in the scalp hair samples of Pakistani male and female referents, (CI, 1.29, 1.99) and $(\mathrm{CI}, 1.35,1.87) \mu \mathrm{g} / \mathrm{g}$, respectively, were found to be lower than those in male and female Pakistani hypertensive patients, (CI, 2.79, 3.17) and (CI, 2.05, 3.03) $\mu \mathrm{g} / \mathrm{g}$, respectively, $(\mathrm{p}=0.001 ;$ Table 8$)$.

An elevated level of $\mathrm{Pb}$ content was observed in the scalp hair of male and female Irish hypertensive patients of both countries. The ranges of $\mathrm{Pb}$ in the scalp hair samples of male Irish and Pakistani referent were (CI, 3.15- 3.58) and (CI, 5.97-6.50) $\mu \mathrm{g} / \mathrm{g}$, respectively, whereas those in Irish and Pakistani hypertensive male patients were (CI, 5.14-5.25) and (CI, 5.01-5.17) $\mu \mathrm{g} / \mathrm{g}$, respectively, $(\mathrm{p}<0.002)$. The same trend was observed in female cases (Tables 7 and 8).

The levels of $\mathrm{Ni}$ in the scalp hair samples of male Irish and Pakistani referent were found to be lower, (CI, 1.69-2.03) and (CI, 3.63-4.93) $\mu \mathrm{g} / \mathrm{g}$, respectively, compared with those in Irish and Pakistani hypertensive patients, (CI, 3.85- 4.06) and (CI, 7.02- 8.55) $\mu \mathrm{g} / \mathrm{g}$, respectively. The same trend was observed in females (Table 7 and 8) (p>0.001).

\section{Discussion}

The present study brings out data related to the metal distribution in hair in terms of parameters such as spread around mean metal concentrations, possible correlations, origin identification, and comparative evaluation of the two classes of donors. Tables 7 and 8 present basic distribution parameters pertaining to selected metals in hair samples of Irish and Pakistani donors of both genders, respectively. 
There are many causes of high blood pressure, such as smoking, obesity, poor diet (lack of cold water fish, fresh fruits, and vegetables), lack of exercise, poor sleep, genetics, stress, and insomnia. Drinking too much alcohol can raise the levels of some fats in the blood (triglycerides). It can also lead to high blood pressure, heart failure, and an increased calorie intake. Excessive drinking and binge drinking can lead to stroke. Other serious problems include fetal alcohol syndrome, cardiomyopathy, and sudden cardiac death.

Toxic elements $(\mathrm{Cd}, \mathrm{Pb}$, and $\mathrm{Ni})$ may deplete glutathione and protein-bound sulfhydryl groups, resulting in the production of reactive oxygen species, such as superoxide anion, hydrogen peroxide, and hydroxyl radical [19]. In the past few years, increasing consideration has been given to interactions occurring in the organism between toxic metals and bioelements essential for life.

These interactions are complex and involve biometals such as zinc, copper, iron, selenium, calcium, and toxic elements, including cadmium [20]. The basis of Cd toxicity is its negative influence on enzymatic systems of cells, resulting from substitution of other essential metal ions (mainly $\mathrm{Zn}, \mathrm{Cu}$, and $\mathrm{Ca}$ ) in metalloenzymes and its very strong affinity to biological structures containing - $\mathrm{SH}$ groups, such as proteins, enzymes, and nucleic acids [12]. The relevance of $\mathrm{Cd}, \mathrm{Pb}, \mathrm{Ni}, \mathrm{Cu}$, and $\mathrm{Fe}-\mathrm{Zn}$ interactions should be considered in the light of the general population exposure to toxic metals [21] and the common deficiency of $\mathrm{Zn}$ in the world, mainly due to nutritional factors [22]. The concentrations of zinc in the scalp hair samples of the Irish and Pakistani hypertensive patients of both genders were lowered (Tables 7 and 8). Zinc deficiency causes the arteries to become hard, brittle, and often inflamed instead of soft and flexible.

This loss of flexibility will raise the blood pressure, in particular the systolic pressure [23, 24]. In the case of hypertensive patients, vegetarian foods have high phytate, and their intake may result in reduced availability of iron and zinc for intestinal absorption [25]. The $\mathrm{Pb}, \mathrm{Cd}$, and $\mathrm{Ni}$ in the occupational hypertensive persons from urban areas were significantly higher [26] as compared with normal subjects. Smoking was found to be a contributing factor to higher bioaccumulation of $\mathrm{Cd}$ as also reported by other researchers [27]. Workers with chronic headache and dizziness have higher levels of $\mathrm{Cr}$ and $\mathrm{Pb}$ in the scalp hair samples, such as those working in a fireworks factory [28]. It was observed in our studies that the level of nickel was significantly higher in hypertensive subjects as compared with normotensive age-matched subjects (Table 8). Significant Ni levels in smokers compared with nonsmokers have also been reported at significant level of $p>0.001$ [29]. Besides this, the inhalation of vapors of nickel carbonyl certain occupations (welding, fitting, etc.) also causes elevated $\mathrm{Ni}$ levels in biological samples [30,31].

This is the first study with comprehensive data on toxic and essential elements in the scalp hair samples of hypertensive and referent subjects of two countries (Pakistan and Ireland). The concentrations of essential trace and toxic elements in scalp hair samples of the Irish referent subjects were close to those reported from other European [32-38], American [3942], and Australian [43] countries (Table 9). The elemental concentrations of $\mathrm{Cd}, \mathrm{Pb}$, and $\mathrm{Ni}$ 
in Pakistani referents were almost higher than in European countries, which is in agreement with the studies which were done in Asian [44-58] and African [59-63] countries (Table 9).

\begin{tabular}{|c|c|c|c|c|}
\hline \multicolumn{5}{|l|}{ Europe } \\
\hline \multicolumn{5}{|l|}{ Sweden } \\
\hline Authors & Elements & Age (years) & $N$ & $x \pm s(\mu \mathrm{g} / \mathrm{g})$ \\
\hline \multirow[t]{4}{*}{ Rodushkin and Axelsson 2000 [32] } & $\mathrm{Pb}$ & $1-75$ & 114 & $0.22-7.26$ \\
\hline & $\mathrm{Cd}$ & $1-75$ & 114 & $0.010-0.356$ \\
\hline & $\mathrm{Zn}$ & $1-75$ & 114 & $68-198$ \\
\hline & $\mathrm{Ni}$ & $1-75$ & 114 & $0.11-1.60$ \\
\hline \multicolumn{5}{|l|}{ England } \\
\hline Reilly and Harrison 1979 [33] & $\mathrm{Zn}$ & $16-25$ & 215 & $210-235$ \\
\hline \multicolumn{5}{|l|}{ Poland } \\
\hline \multirow[t]{4}{*}{ Nowak and Chmielnicka 2000 [34] } & $\mathrm{Pb}$ & $25-39$ & 624 & $4.8-5.7$ \\
\hline & $\mathrm{Cd}$ & $25-39$ & 624 & $0.56 \pm 2.3$ \\
\hline & $\mathrm{Zn}$ & $25-39$ & 624 & $132.7 \pm 135.7$ \\
\hline & $\mathrm{Ni}$ & $25-39$ & 624 & $1.1 \pm 5.4$ \\
\hline \multirow[t]{4}{*}{ Trojanowski et al. 2010 [35] } & $\mathrm{Pb}$ & $26-50$ & 109 & $3.71 \pm 0.29$ \\
\hline & $\mathrm{Cd}$ & & 109 & $0.401 \pm 0.035$ \\
\hline & $\mathrm{Pb}$ & $51-75$ & 121 & $3.88 \pm 0.35$ \\
\hline & $\mathrm{Cd}$ & & 121 & $0.260 \pm 0.022$ \\
\hline \multicolumn{5}{|l|}{ Italy } \\
\hline \multirow[t]{3}{*}{ Sturaro et al. 1993 [36] } & $\mathrm{Ni}$ & $21-60$ & 50 & $1.4-3.2$ \\
\hline & $\mathrm{Zn}$ & $21-60$ & 50 & $171-314$ \\
\hline & $\mathrm{Pb}$ & $21-60$ & 50 & $6.5-8.7$ \\
\hline \multicolumn{5}{|l|}{ France } \\
\hline \multirow[t]{3}{*}{ Goulle et al. 2005 [37] } & $\mathrm{Ni}$ & $40-60$ & 45 & $0.08-0.90$ \\
\hline & $\mathrm{Zn}$ & $40-60$ & 45 & 129-209 \\
\hline & $\mathrm{Pb}$ & $40-60$ & 45 & $0.13-4.57$ \\
\hline \multicolumn{5}{|l|}{ Netherlands } \\
\hline 7Iyengar and Wolttlez 1988 [38] & $\mathrm{Zn}$ & $21-60$ & 50 & $176 \pm 38$ \\
\hline \multicolumn{5}{|l|}{ South America } \\
\hline Nagra et al. 1992 [39] & $\mathrm{Cd}$ & $22-59$ & 50 & $31.6 \pm 38$ \\
\hline Ryan et al. 1978 [40] & $\mathrm{Zn}$ & $20-55$ & 42 & $108-357$ \\
\hline \multicolumn{5}{|l|}{ North America } \\
\hline \multirow[t]{2}{*}{ Saiki et al. 2008 [41] } & $\mathrm{Zn}$ & $50-70$ & 50 & $45-162$ \\
\hline & $\mathrm{Zn}$ & $71-87$ & 50 & $30-202$ \\
\hline DeAntonloet al. 1982 [42] & $\mathrm{Zn}$ & $15-35$ & 67 & $90-294$ \\
\hline \multicolumn{5}{|l|}{ Australia } \\
\hline McKenzie 1979 [43] & $\mathrm{Zn}$ & $16-56$ & 118 & $189 \pm 24$ \\
\hline \multicolumn{5}{|l|}{ Asia } \\
\hline \multicolumn{5}{|l|}{ Pakistan } \\
\hline \multirow[t]{4}{*}{ Pasha et al. 2008 [44] } & $\mathrm{Pb}$ & 15-94 year & 86 & $14.62 \pm 8.01(0.577-31.8)$ \\
\hline & $\mathrm{Cd}$ & $15-94$ year & 86 & $2.13 \pm 1.74(0.196-9.17)$ \\
\hline & $\mathrm{Zn}$ & $15-94$ year & 86 & $154.2 \pm 117.1(12.4-729.2)$ \\
\hline & $\mathrm{Ni}$ & 15-94 year & 86 & $3.82 \pm 2.85(0.068-11.8)$ \\
\hline Pasha et al. 2010 [45] & $\mathrm{Pb}$ & $37-65$ & 37 & $15.50 \pm 8.11$ \\
\hline
\end{tabular}




\begin{tabular}{|c|c|c|c|c|}
\hline Europe & & & & \\
\hline \multirow{11}{*}{ Shah et al. 2006 [46] } & $\mathrm{Cd}$ & $37-65$ & 37 & $1.675 \pm 1.13$ \\
\hline & $\mathrm{Zn}$ & $37-65$ & 37 & $140.7 \pm 79.5$ \\
\hline & $\mathrm{Ni}$ & $37-65$ & 37 & $4.309 \pm 2.63$ \\
\hline & \multirow[t]{2}{*}{$\mathrm{Pb}$} & $3-54$ & 62 & $15.97 \pm 5.56$ \\
\hline & & $3-54$ & 62 & $24.95 \pm 8.69$ \\
\hline & \multirow[t]{2}{*}{$\mathrm{Cd}$} & $3-54$ & 62 & $0.38 \pm 0.186$ \\
\hline & & $3-54$ & 62 & $0.53 \pm 0.26$ \\
\hline & \multirow[t]{2}{*}{$\mathrm{Zn}$} & $3-54$ & 62 & $226 \pm 53.7$ \\
\hline & & $3-54$ & 62 & $190 \pm 34.0$ \\
\hline & \multirow[t]{2}{*}{$\mathrm{Ni}$} & $3-54$ & 62 & $2.46 \pm 1.95$ \\
\hline & & $3-54$ & 62 & $1.99 \pm 1.64$ \\
\hline \multirow[t]{3}{*}{ Khalique et al. 2005 [47] } & $\mathrm{Cd}$ & $41-50$ & 18 & $0.300 \pm 0.140$ \\
\hline & $\mathrm{Zn}$ & $41-50$ & 18 & $270 \pm 46.5$ \\
\hline & $\mathrm{Ni}$ & $41-50$ & 18 & $5.45 \pm 1.03$ \\
\hline \multicolumn{5}{|l|}{ India } \\
\hline \multirow[t]{4}{*}{ Vishwanathan et al. 2002 [48] } & $\mathrm{Pb}$ & $36 \pm 1.23$ & 25 & $24.8 \pm 5.92$ \\
\hline & $\mathrm{Cd}$ & $36 \pm 1.23$ & 25 & $5.12 \pm 3.41$ \\
\hline & $\mathrm{Zn}$ & $36 \pm 1.23$ & 25 & $265.2 \pm 17.3$ \\
\hline & $\mathrm{Ni}$ & $36 \pm 1.23$ & 25 & $6.48 \pm 1.09$ \\
\hline \multirow[t]{8}{*}{ Sukumar and Subramanian 2003 [49] } & $\mathrm{Pb}$ & $31-45$ & 17 & $8.9 \pm 1.9$ \\
\hline & & $46-60$ & 11 & $4.5 \pm 2.8$ \\
\hline & $\mathrm{Cd}$ & $31-45$ & 17 & $1.5 \pm 0.3$ \\
\hline & & $46-60$ & 11 & $1.9 \pm 0.5$ \\
\hline & $\mathrm{Zn}$ & $31-45$ & 17 & $87.0 \pm 1.9$ \\
\hline & & $46-60$ & 11 & $112.8 \pm 25.3$ \\
\hline & $\mathrm{Ni}$ & $31-45$ & 17 & $0.8 \pm 0.2$ \\
\hline & & $46-60$ & 11 & $1.0 \pm 0.5$ \\
\hline \multirow[t]{4}{*}{ Mehra and Juneja 2005 [50] } & $\mathrm{Pb}$ & $1-30$ & 50 & $7.60 \pm 6.44$ \\
\hline & $\mathrm{Cd}$ & $1-30$ & 50 & $0.32 \pm 0.21$ \\
\hline & $\mathrm{Zn}$ & $1-30$ & 50 & $182.4 \pm 45.2$ \\
\hline & $\mathrm{Ni}$ & $1-30$ & 50 & $25.3 \pm 15.7$ \\
\hline \multirow[t]{4}{*}{ Rao et al. 2002 [51] } & $\mathrm{Cd}$ & $17-60$ & 20 & $0.12-0.61$ \\
\hline & $\mathrm{Ni}$ & $17-60$ & 20 & $0.72-1.61$ \\
\hline & $\mathrm{Zn}$ & $17-60$ & 20 & $45.44-123.5$ \\
\hline & $\mathrm{Pb}$ & $17-60$ & 20 & $0.75-4.1$ \\
\hline \multicolumn{5}{|l|}{ Bangladesh } \\
\hline \multirow[t]{2}{*}{ Rahman et al. 2009 [52] } & $\mathrm{Zn}$ & - & 30 & $199.16 \pm 27.85$ \\
\hline & $\mathrm{Cd}$ & - & 30 & $0.47 \pm 0.32$ \\
\hline \multicolumn{5}{|l|}{ Turkey } \\
\hline \multirow[t]{2}{*}{ Sasmaz et al. 2003 [53] } & $\mathrm{Pb}$ & - & 26 & $3.06 \pm 1.42$ \\
\hline & $\mathrm{Cd}$ & - & 26 & $0.67 \pm 0.33$ \\
\hline Ulvi et al. 2002 [54] & $\mathrm{Zn}$ & $47.76 \pm 13.11$ years & 29 & 176.96 \\
\hline \multicolumn{5}{|l|}{ Iran } \\
\hline Faghihian and Rahbarnia 2002 [55] & $\mathrm{Zn}$ & $14-67$ years & 100 & $36-329$ \\
\hline
\end{tabular}




\begin{tabular}{|c|c|c|c|c|}
\hline Europe & & & & \\
\hline \multicolumn{5}{|l|}{ Hong Kong } \\
\hline \multirow[t]{2}{*}{ Man and Zheng 2002 [56] } & $\mathrm{Pb}$ & 20-50 years & 30 & $12.04 \pm 7.0$ \\
\hline & $\mathrm{Zn}$ & $20-50$ years & 30 & $184.85 \pm 60.89$ \\
\hline Man et al. 1996 [57] & $\mathrm{Zn}$ & $30-69$ years & 95 & $355-503$ \\
\hline \multicolumn{5}{|l|}{ China } \\
\hline Sandstead et al. 1998 [58] & $\mathrm{Zn}$ & $7-25$ years & 662 & $109-155$ \\
\hline \multicolumn{5}{|l|}{ Africa } \\
\hline \multicolumn{5}{|l|}{ Nigeria } \\
\hline \multirow[t]{4}{*}{ Nnorom et al. 2005 [59] } & $\mathrm{Pb}$ & $1-30$ years & 46 & 63.6 \\
\hline & $\mathrm{Cd}$ & $1-30$ years & 46 & 1.0 \\
\hline & $\mathrm{Zn}$ & $1-30$ years & 46 & 128.6 \\
\hline & $\mathrm{Ni}$ & $1-30$ years & 46 & 19.5 \\
\hline \multicolumn{5}{|l|}{ Saudi Arabia } \\
\hline Hashem and Abed 2007 [60] & $\mathrm{Cd}$ & $20-25$ years & 20 & $0.035 \pm 0.007$ \\
\hline \multicolumn{5}{|l|}{ Syria } \\
\hline \multirow[t]{3}{*}{ Khuder et al. 2008 [61] } & $\mathrm{Pb}$ & 21-59 years & 281 & $10.7 \pm 8.9$ \\
\hline & $\mathrm{Zn}$ & $21-59$ years & 281 & $260 \pm 113$ \\
\hline & $\mathrm{Ni}$ & $21-59$ years & 281 & $2.58 \pm 1.19$ \\
\hline \multicolumn{5}{|l|}{ Sudan } \\
\hline \multirow[t]{2}{*}{ Eltayeb and Van-Grieken 1989 [62] } & $\mathrm{Zn}$ & $30-50$ years & 35 & $89-170$ \\
\hline & $\mathrm{Pb}$ & $30-50$ years & 35 & $3-17$ \\
\hline \multicolumn{5}{|l|}{ Egypt } \\
\hline \multirow[t]{2}{*}{ Mortada et al. 2002 [63] } & $\mathrm{Pb}$ & $28-40$ years & 93 & $1.8-9.7$ \\
\hline & $\mathrm{Cd}$ & $28-40$ years & 93 & $0.08-0.82$ \\
\hline
\end{tabular}

There are a number of factors contributing to the higher levels of cadmium and lead in congested areas of Pakistan and other Asian countries. In Asian countries, there are many populated areas which represent a typical urban environment with heavy traffic load, high population density, and industrial units. In addition, open burning of plastics and brick making among other activities contribute to this higher level of toxic elements. Our study revealed that the levels of cadmium and lead in hair were higher in Hyderabad City, suggesting that dust containing these heavy metals is attached to hair samples due to a typical urban environment with heavy traffic load, high population density, and industrial activities. Cadmium, which enters the environment from mining, industry, vehicles, and household waters, binds strongly to soil particles or dissolves in water [64]. Once taken up by fish, plants, and animals, cadmium stays in the body for a long time [65]. Humans are also affected by cadmium through smoking and consumption of foods and beverages. Rice is the main source of cadmium in rice-eating countries. Human lead exposure is mainly through air and food. The presence of lead in fuels has contributed much of the current human exposure [66]. In most developed countries, the fuel content of lead has been controlled but still remains an issue of immediate consideration in developing countries, including Pakistan. Other sources of lead exposure include lead-based paints, lead pipelines in water supply systems, and ceramics. Lead-based products, including paints and food containers, are not completely banned in Pakistan [67]. 
The accumulation of cadmium in the human body may replace zinc in the arteries, which contributes to arteries becoming brittle and inflexible. Cadmium accumulates in the kidneys, resulting in high blood pressure and kidney disease. Therefore, cadmium is known to cause arterial hypertension [68]. Death rates in hypertensive heart disease are closely correlated with cadmium in air and milk [68]. Cadmium causes significant increases in blood pressure [69]. High levels of lead have been identified in significant numbers of patients with high blood pressure [70]. Lead may also replace zinc and calcium, contributing to this cause of hypertension [70]. Once the arteries become inflamed and brittle, the body may coat them with calcium and fatty plaques to prevent rupture of the arteries. This plaque unfortunately reduces the interior diameter of the arteries, which in turn raises blood pressure. More pressure is required to force the blood through the smaller diameter arteries. Toxic substances can build up within the kidneys and damage their ability to regulate water balance in the body. This can lead to water retention, salt retention, and high blood pressure.

\section{Conclusion}

The present study showed a marked hair metal concentration dependence on geographic location, environmental exposure, and dietary habits of the donors. The observed variations in metal concentrations in hair of referents and hypertensive patients of two donor groups (Pakistan and Ireland) reflected different food habits and geographic location as causatives that collectively affected individual variability and metabolic activity. In addition, environmental exposure emerged as a critical covariate that was found to overload the city atmosphere of Hyderabad, Pakistan, due to $\mathrm{Cd}, \mathrm{Ni}$, and $\mathrm{Pb}$ pollution arising from automobile exhaust emissions. In general, the local habitants of Dublin, Ireland, were not critically exposed to the adverse effects of environmental trace metal pollution, as has been observed for mega cities of the world. The present data could act as baseline information for relevant futuristic studies. The results of this study revealed that hypertensive patients have a different pattern of essential trace and toxic elements in their scalp hair samples than do controls/referents. However, higher levels of $\mathrm{Cd}, \mathrm{Cu}, \mathrm{Fe}, \mathrm{Pb}$, and $\mathrm{Ni}$, as well as a lower level of $\mathrm{Zn}$, correlated well with the consequences of HT. The deficiency of the essential element, $\mathrm{Zn}$, which is replaced by trace and toxic elements $(\mathrm{Cd}, \mathrm{Pb}$, and $\mathrm{Ni})$, may result in abnormal physiology disorders, and, in addition to other factors, this may have a role in hypertensive and cardiovascular disease. We propose that essential and toxic elemental measurements may be performed on patients reaching in the emergency department, to test whether the concentration of it may serve not only as markers of hypertension and its remedies but also as predictors of adverse outcomes.

\section{References}

1. Burt VL, Whelton P, Roccella EJ, Brown C, Cutler JA, Higgins M (1995) Prevalence of hypertension in the US adult population. Results from the Third National Health and Nutrition Examination Survey, 1988-1991. Hypertension 25:305-313 
2. Privitera JR, Stang A (1996) Silent clots-life's biggest killers. The Catacombs Press, Covina, pp 1-55

3. American Academy of Pediatrics (2000) October 1998 Child Health Month Report. The risks of tobacco use: a message to parents and teens; Milam JE. Perceived invulnerability and cigarette smoking among adolescents. Addict Behav 25:71-80

4. Soylak M, Kidnap M (2001) Serum copper and zinc concentrations of patients with rheumatoid arthritis from Kayseri-Turkey. Fresenius Environ Bull 10:409-410

5. Hennig B, Meerarani P, Toborek M, Mc-Clain C (1999) Antioxidant-like properties of zinc in activated endothelial cells. J Am Coll Nutr 18:152-158

6. Memon AR, Kazi TG, Afridi HI, Jamali MK, Arain MB, Jalbani N et al (2007) Evaluation of zinc status in whole blood and scalp hair of female cancer patients. Clin Chim Acta 379:66-70

7. Lauwerys R, Bernard A, Roels H, Buchet JP (1994) Cadmium: exposure markers as predictors of nephrotoxic effects. Clin Chem 40(7):1391-1394

8. Jonnalagadda S (1993) Toxicity, bioavailability and metal speciation. Comp Biochem Physiol C 106 (3):585-595

9. Engvall J, Perk J (1985) Prevalence of hypertension among cadmium exposed workers. Arch Environ Health 40(3):185-190

10. DHHS (1999) Toxicological profile for lead. Agency for Toxic Substances and Disease Registry, US Department of Health and Human Services. Atlanta, GA

11. International Agency for Research on Cancer (1989). Monograph on the evaluation of carcinogenic risks to humans: chromium, nickel and welding Vol. 49. IARC, Lyon

12. Stohs SJ, Bagchi D (1995) Oxidative mechanisms in the toxicity of metal ions. Free Radic Biol Med 18:321-336

13. Nawrot TS, Thijs L, Den Hond EM, Roels HA, Staessen JA (2002) An epidemiological reappraisal of the association between blood pressure and blood lead: a meta-analysis. J Hum Hypertens 16:123-131

14. Witte KKA, Nikitin NP, Parker AC, von Haehling S, Volk HD, Anker SD et al (2005) The effect of micronutrient supplementation on quality-of-life and left ventricular function in elderly patients with chronic heart failure. Eur Heart J 26:2238-2244

15. Kazi TG, Afridi HI, Kazi N, Jamali MK, Arain MB, Jalbani N, Baig JA (2008) Distribution of zinc, copper and iron in biological samples of Pakistani myocardial infarction (1st, 2nd and 3rd heart attack) patients and controls. Clin Chim Acta 389:114-119 
16. Afridi HI, Kazi TG, Kazi N, Jamali MK, Arain MB, Jalbani N, Shah AQ (2008) Evaluation of status of toxic metals in biological samples of diabetes mellitus patients. Diab Res Clin Pract 80:280-288

17. Afridi HI, Kazi TG, Kazi GH (2006) Analysis of heavy metals in scalp hair samples of hypertensive patients by conventional and microwave digestion methods. Spectrosc Lett 39:203-214

18. Cho SY, Awh OD, Chung YJ, Chung YJ (1997) Trace element exposure in man by instrumental neutron activation analysis of hair. J Radioanal Nucl Chem 217:107-109

19. Goyer RA (1996) Toxic effects of metals. In: Klaassen CD (ed) Casarett and Doull's toxicology: the basic science of poisons, vol 5. New York, McGraw-Hill, pp 691-736

20. Brzoska MM, Moniuszko-Jakoniuk J, Jurczuk M, Chraniuk M (1997) The influence of cadmium on bone tissue in rats. Pol J Environ Stud 6:29-32

21. Waalkes MP, Coogan TP, Barter RA (1992) Toxicological principles of metal carcinogenesis with special emphasis on cadmium. Crit Rev Toxicol 22:175-201

22. Lonnerdal B (1993) Dietary factors influencing zinc absorption. J Nutr 130:1378-1383

23. Fabris N, Mocchegiani E (1995) Zinc, human diseases and aging. Aging Milano 7(2):7793

24. Subramanian R, Sukumar A (1988) Biological reference materials and analysis of toxic elements. Fresenius Z Anal Chem 332:623-629

25. Klevay LM (1974) Hair as a biopsy material and geographic variations in the concentrations of zinc. Nutr Rep Int 10:181-187

26. Arunachalam J, Gangadharan S, Yengnasubramanian S (1979) Elemental data on human hair sampled from Indian student population and their interpretation for studies in environmental exposure in nuclear activation technique in Life Science. IAEA-SM 227(24):499-513

27. Chattopadhyay P, Joshi H, Samaddar K (1990) Hair cadmium level of smoker and nonsmoker human volunteers in and around Calcutta city. Bull Environ Contam Toxicol 45:177-180

28. Sukumar A, Subramanian R (1992) Elements in hair and nails of residents from a village adjacent to New Delhi: influence of place of occupation and smoking habits. Biol Trace Elem Res 34:99-105

29. Wolfsperger M, Hauser G (1994) Heavy metals in human hair samples from Austria and Italy: influence of sex and smoking habits. Sci Total Environ 156(3):235-242

30. Sunderman FW (1988) Acute nickel toxicity in electroplating workers who accidentally ingested a solution of nickel sulfate and nickel chloride. Am J Ind Med 14:257-266 
31. Doll R (1990) Report of the international committee on nickel carcinogenesis in man. Scand J Work Environ Health 16:1-84

32. Rodushkin I, Axelsson MD (2000) Application of double focusing sector field ICP-MS for multielemental characterization of human hair and nails. Part II. A study of the inhabitants of northern Sweden. Sci Total Environ 262:21-36

33. Reilly C, Harrison F (1979) Zinc, copper, iron and lead in scalp hair of students and nonstudent adults in Oxford. J Human Nutr 33(4):248-252

34. Nowak B, Chmielnicka J (2000) Relationship of lead and cadmium to essential elements in hair, teeth, and nails of environmentally exposed people. Ecotoxic Environ Saf 46:265-274

35. Trojanowski P, Trojanowski J, Antonowicz J, Bokiniec M (2010) Lead and cadmium content in human hair in central Pomerania (northern Poland). J Elementol 15(2):363-384

36. Sturaro A, Parvoli G, Doretti L (1993) Simultaneous determination of trace metals in human hair by dynamic ion-exchange chromatography. Anal Chim Acta 274:163-170

37. Goulle JP, Mahieu L, Castermant J, Neveu N, Bonneau L, Laine G, Bouige D, Lacroix C (2005) Metal and metalloid multi-elementary ICP-MS validation in whole blood, plasma, urine and hair reference values. Forensic Sci Int 153:39-44

38. Iyengar V, Wolttlez J (1988) Trace elements in human clinical specimens: evaluation of literature data to identify reference values. Clin Chem 34(3):474-481

39. Nagra MS, Pallah BS, Sahota GPS, Singh H, Sahota HS (1992) A study of trace elements in scalp hair and fingernails of industrial workers of Ontario, Canada. J Radioanal Nucl Chem 162(2):283-288

40. Ryan DE, Holzbecher J, Stuart DC (1978) Trace elements in scalp-hair of persons with multiple sclerosis and of normal individuals. Clin Chem 24(11):1996-2000

41. Saiki M, Alves ER, Jaluu 0, Sumita NM, Filho WJ (2008) Determination of trace elements in scalp hair of an elderly population by neutron activation analysis. J Radioanal Nucl Chem 276(1):53-57

42. DeAntonlo SM, Katz SA, Schemer DM, Wood JO (1982) Anatomically-related variations in trace-metal concentrations in hair. Clin Chem 28(12):2411-2413

43. McKenzie JM (1979) Content of zinc in serum, urine hair and toenails of New Zealand adults. Am J Clin Nutr 32:570-579

44. Pasha Q, Malik SA, Iqbal J, Shaheen N, Shah MH (2008) Comparative distribution of the scalp hair trace metal contents in the benign tumour patients and normal donors. Environ Monit Assess 147:377-388 
45. Pasha Q, Malik SA, Shaheen N, Shah MH (2010) Investigation of trace metals in the blood plasma and scalp hair of gastrointestinal cancer patients in comparison with controls. Clin Chim Acta 411:531-539

46. Shah MH, Shaheen N, Khalique A, Alrabti AAA, Jaffar M (2006) Comparative metal distribution in hair of Pakistani and Libyan population and source identification by multivariate analysis. Environ Monit Assess 114:505-519

47. Khalique A, Ahmad S, Anjum T, Munir JM, Shah H, Shaheen N, Tariq SR, Manzoor S (2005) A comparative study based on gender and age dependence of selected metals in scalp hair. Environ Monit Assess 104:45-57

48. Vishwanathan H, Hema A, Edwin D, Usha Rani MV (2002) Trace metal concentration in scalp hair of occupationally exposed autodrivers. Environ Monit Assess 77:149-154

49. Sukumar A, Subramanian (2003) Elements in the hair of non-mining workers of a lignite open mine in Neyveli. Ind Health 41(2):63-68

50. Mehra R, Juneja M (2005) Elements in scalp hair and nails indicating metal body burden in polluted environment. J Sci Ind Res 64(2):119-124

51. Rao KS, Balaji T, Rao TP, Babu Y, Naidu GRK (2002) Determination of iron, cobalt, nickel, manganese, zinc, copper, cadmium and lead in human hair by inductively coupled plasmaatomic emission spectrometry. Spectrochim Acta B 57:1333-1338

52. Ashrafur RM, Kalam AMA, Iqbal HM, Shalahuddin QMMA, Wasimul B, Farida B, Imamul HSM, Abul H (2009) Zinc, manganese, calcium, copper, and cadmium level in scalp hair samples of schizophrenic patients. Biol Trace Elem Res 127:102-108

53. Sasmaz S, Uz E, Pinar T, Vural H, Eiri M, Ilihan A, Akyol 0 (2003) Hair lead and cadmium concentrations in patients with epilepsy and migraine. Neurosci Res Commun 32:107-114

54. Ulvi H, Yigiter R, Yoldas TS, Dolu Y, Var A, Mungen B (2002) Magnesium, zinc and copper contents in hair and their serum concentrations in patients with epilepsy. Eastern $\mathbf{J}$ Medicine 7:31-35

55. Faghihian H, Rahbarnia H (2002) Determination of trace elements in hair of some local population in Iran by instrumental neutron activation analysis. J Radioanal Nucl Chem 251:427-430

56. Man CK, Zheng YH (2002) Analysis of trace elements in scalp hair of mentally retarded children. J Radioanal Nucl Chem 253:375-377

57. Man CK, Zheng YH, Mak PK (1996) Trace element profiles in the hair of nasopharyngeal carcinoma (NPC) patients. J Radioanal Nucl Chem Letters 212:151-160 
58. Sandstead HH, Penland JG, Alcock NW, Dayal HH, Chen XC, Li JS, Zhao F, Yang JJ (1998) Effects of repletion with zinc and other micronutrients on neuropsychologic performance and growth of Chinese children. Am J Clin Nutr 68:470S-475S

59. Nnorom IC, Igwe JC, Ejimone JC (2005) Multielement analyses of human scalp hair samples from three distant towns in southeastern Nigeria. African J Biotech 4:1124-1127

60. Hashem AR, Abed KF (2007) Aluminum, cadmium and microorganisms in female hair and nails from Riyadh. Saudi Arabia J Medical Sci 7:263-266

61. Khuder A, Bakir MA, Hasan R, Mohammad A (2008) Determination of nickel, copper, zinc and lead in human scalp hair in Syrian occupationally exposed workers by total reflection X-ray fluorescence. Environ Monit Assess 143:67-74

62. Eltayeb MAH, Van-Grieken RE (1989) Preconcentration and XRF determination of heavy metals in hair from Sudanese populations. J Radioanal Nucl Chem 131:331-342

63. Mortada WI, Sobh MA, El-Defrawy MM, Farahat SE (2002) Reference intervals of cadmium, lead, and mercury in blood, urine, hair, and nails among residents in Mansoura City, Nile Delta, Egypt. Environmental Research Section A 90:104-110

64. Agency for Toxic Substances and Disease Registry (ATSDR) (1993) Toxicological profile for cadmium. U.S. Public Health Service, U.S. Department of Health and Human Services. Atlanta, GA

65. Agency for Toxic Substances and Disease Registry (ATSDR) (1999) Public Health Statement for Cadmium; U.S. Public Health Service, U.S. Department of Health and Human Services: Atlanta, GA

66. Zuliani G, Perin G, Rausa G (1966) Determination of organic lead in presence of inorganic lead in the atmosphere surrounding fuel distributors. Med Lay 12:771-780

67. Hozharbi S (2002) Lead-based paint is a hazard to young children: implications for Pakistani children. J Pak Med Assoc 5:224-226

68. Malinow MR (1996) Plasma homocyst(e)ine: a risk factor for arterial occlusive diseases. J Nutr 126:1238-1243

69. Schroeder HA, Nason AP, Tipton NI, Balassa JJ (1967) Essential trace elements in man: zinc: relation to environmental cadmium. J Chronic Dis 20:179

70. Staessen JA, Roels H, Fagard R (1996) Lead exposure and conventional and ambulatory blood pressure: a prospective population study, PheeCad Investigators. JAMA 275(20):16041606 